\title{
The Dimensions of Entrepreneurial Orientation And Its Impact On Business Performance
}

\author{
Hartelina \\ Fakultas Ekonomi - Universitas Palangkaraya \\ Email : hartalina@eco.upr.ac.id
}

\begin{abstract}
Entrepreneurship attracted the attention of many parties, both academics and business practitioners. Entrepreneurship is believed to be one solution, so that the business can survive in the fierce competition. The company must have a strong entrepreneurial orientation. This study aimed to examine the effect of the dimensions of entrepreneurial orientation, individually on business performance. This research is a quantitative approach. The unit of analysis is the company in the restaurant industry. Data were collected by questionnaire. By using purposive sampling method, we have selected 112 restaurants, as a sample. Respondent is head of the company. Data were analyzed using multiple regression. The results showed that the dimensions of entrepreneurial orientation, which consists of autonomy, innovation, proactive, competitive aggressiveness and risk-taking, has a significant positive effect on the performance and marketing, operating performance and profitability, which is the dimension of business performance. This result proves that the entrepreneurial orientation, is an important aspect of a business.
\end{abstract}

Keywords : Entrepreneurial Orientation, Marketing Performance, Operating Performance, Profitability

\section{INTRODUCTION}

Restaurant is a dynamic industry. Expectations and changes in consumer tastes, is rapidly changing. Competition in the restaurant industry also occur very strict, not only among fellow restaurant, but also with other sectors of business. In short, to be able to survive and generate maximum profits, a restaurant should be able to operate effectively and efficiently, and able to adapt to changing consumer tastes.

One approach, which is now believed to be a force to competing is entrepreneurial orientation (EO). Among academia, entrepreneurship becomes an interesting topic to be explored further. Some studies focus on entrepreneurial character traits in the several races [1]. Other studies analyze the entrepreneurship associated with national culture, which concluded that there are indications that national culture affects the character of the entrepreneur [2].

Several studies have proven that the entrepreneurial orientation positive effect on the performance of companies [3], [4], [5], [6], [7], [8]. EO is a construct that can promote the growth of micro and small enterprise in Kenya [9]. However, studies that specifically link each dimension of the EO to business performance has not been much.

This study aimed to examine the effect of the dimensions of EO on business performance, which is include marketing performance, operating performance, and profitability.

\section{LITERATURE REVIEW}

\section{A. Definition Of Entrepreneurial Orientation}

An entrepreneurial orientation refers to the processes, practices, and decision-making activities that lead to new entry. It emerges from a strategic-choice perspective, which asserts that new-entry opportunities can be successfully undertaken by "purposeful enactment". Thus, it involves the intentions and actions of key players functioning in a dynamic generative process aimed at new-venture creation [10].

Entrepreneurial Orientation is used to refer to a set of personal psychological traits, values, attributes and attitudes that are strongly associated with the motivation to carry out entrepreneurial activity. Entrepreneurial orientation is an enterprise-level constructs that are closely related to strategic management and strategic decision making process. Entrepreneurial orientation should be distinguished by entrepreneurship, which is associated with entering new businesses and relating, in particular with the question "What kind of business we enter?" And "How do we make a new business successful?" [11].

Entrepreneurial orientation is a process, structure and behavior of companies that are characterized by innovativeness, proactiveness and risk taking [12]. Entrepreneurial orientation refers to strategic decision-making process that provides organizations with a basis for entrepreneurial decisions and actions [13].

Entrepreneurial orientation is a construct of the enterprise level, multidimensional process that relates closely to the strategic decision making process, which can be distinguished from entrepreneurship, and more attention to methods, practices and decision-making styles are used managers [14]. Entrepreneurial orientation embodies the entrepreneurial organizational level [15].

Entrepreneurial orientation has been conceptualized as the process and decision making activities used by entrepreneurs that leads to entry and support of business activities [16]; and as the strategy- making processes that provide organizations with a basis for entrepreneurial decisions and actions [17]. Thus, entrepreneurial orientation (EO) generally considered as a key ingredient for the success of a firm. EO as a firm's strategic orientation, one which captures the specific entrepreneurial aspects of decision-making styles, methods, and practices [18].

Entrepreneurial orientation consists of five dimensions that permeate the decision-making style and other practices of the 
member organizations [19]. The dimensions are autonomy, innovativeness, proactiveness, competitive aggressiveness and risk taking.

Autonomy is an independent action by an individual or team aimed at bringing forth a business concept or vision and carrying it through to completion. Innovativeness is a willingness to introduce novelty through experimentation and creative processes aimed at developing new product and service as well as new processes. Proactiveness is a forward-looking perspective characteristic of a marketplace leader that has the foresight to seize opportunities in anticipation of future demand. Competitive aaggressiveness is an intense effort to outperform industry rivals characterized by a combative posture or an aggressive response aimed at improving position and overcoming a threat in a competitive market. Risk Taking is making decision and taking action without certain knowledge of probable outcomes; some undertaking may also involve making substantial resources commitments in the process of venturing forward.

In some studies, only include the three dimensions of the EO to be analyzed; innovativeness, risk-taking and proactiveness [20], [21], [22].

\section{B. Impact of The Dimensions of Entrepreneurial Orientation On Business Performance}

Several studies have shown that the EO has a significant impact on business performance [23], [24]. Entrepreneurial orientation affect performance, although there is a role of moderator variables namely social capital [25]

Studies that specifically reveal the role of each dimension of EO (innovativeness, proactiveness, competitive aggressiveness, autonomy and risk taking) on the performance marketing, operating performance and profitability are still relatively few. Mostly, these studies measure the EO as a whole. In this study, we believe that each dimension of EO have a positive contribution to business performance. EO as a firm's strategic orientation, one which captures the specific entrepreneurial aspects of decision-making styles, methods, and practices [26].

Autonomy refers to the desire to act independently in order to continue the entrepreneurial vision or opportunity. It is applied to both individual and team that operates outside of strategies and norms that have been there from an organization. In the context of corporate entrepreneurship, autonomous work units are often used to leverage existing strengths in the new arena, identify opportunities of organizational capability at present, and encourages the development of new businesses or improve business practicess [27].

Innovativeness refers to the company's efforts to acquire new opportunities and new solutions. Innovativeness of the company's attitude towards innovation and the desire to innovate. It includes creativity and experimentation that resulted in new products, new services, or the improvement of technological processes. Innovativeness is one of the main components of entrepreneurial strategies.

Two methods can be used by companies to improve their competitive position through innovativeness dimensions namely: (1) Encouraging creativity and experimentation. Innovation in order to succeed, companies must break the patterns that have shaped their thinking. They also had to create a place for employees to express themselves. (2) Investments in new technologies, $R \& D$, and continuous improvement. For the sake of the success of innovation, companies should look for advantages of the latest technology. This often requires a substantial investment.

Proactiveness refer to the company's efforts to capture new opportunities. Organizations that proactively monitor trends, identify the future needs of existing customers, and anticipate changes in demand and the problems that arise that can lead to new business opportunities. Proactiveness not only recognize the change, but also willing to act on their understanding of the competition. Proactiveness implement strategic managers who have an eye on the future in looking for new opportunities to grow and develop. Many companies are proactively looking for ways not only to the future orientation, but also to change the nature of competition in their industry.

Proactiveness is specifically effective to create a competitive advantage, because it is putting competitors in a position to respond to the initiative successful. The benefit gained by the first company to enter new markets, are building a brand identity, implementing administrative techniques, or adopt new technologies in an industrial operation called first mover advantage.

Furthermore, the company can use two other methods to act proactively: (1) Introducing a new product or technology capabilities in competition, and (2) Continuously looking for products or offering new services.

Competitive aggressiveness referring to the efforts of companies to outperform competitors in the industry. Companies with aggressive orientation willing to "fight" with competitors. They may cut prices and sacrificing profits to gain market share or spending aggressively to obtain manufacturing capacity. As a way of development and growth of the company, competitive aggressiveness can be a very firm stance in exploiting the results of other entrepreneurial activity such as innovativeness or proactiveness.

To improve the competitive position through competitive aggressiveness, how to do is: (1) enter the market with lower costs dramatically, and (2) imitate the business practices or techniques that have been successful from competitors.

Not like innovativeness or proactiveness which tend to focus on market opportunities, competitive aggressiveness directed by competitors. The SWOT analysis provides a useful way to distinguish the different approach for corporate entrepreneurship. Proactiveness is a response of opportunities. While competitive aggressiveness is a response to threat. Aggressiveness a competitive posture is very important for the company to enter new markets that faced with intense rivalry.

Strategic managers, can use competitive aggressiveness against industry trends that threaten the sustainability or their market position. Sometimes companies need to maintain a competitive position in full over backwards which makes them the industry leader. Companies often need to aggressively ensure their advantage by utilizing new technology or to serve the needs of new markets.

Risk-taking refers to the willingness of enterprises to seize the business opportunities despite not knowing whether the business will be successful, or to take bold action without knowing the consequences. To succeed with corporate entrepreneurship, companies typically must take a riskier alternative, even if you need to leave the product or method that has long been used. To achieve high financial returns of companies taking risks such as high levels of borrowing, issuing a large number of company resources, introducing new products in new markets, and investing in technology that has not been explored. 
Based on the above rationale, we propose three hypotheses to be tested as follows:

H1 : The dimensions of the EO, which consists of innovativeness, proactiveness, competitive aggressiveness, autonomy and risk taking, positive effect on the performance of marketing at the restaurant in Bandung.

H2 : The dimensions of the EO, which consists of innovativeness, proactiveness, competitive aggressiveness, autonomy and risk taking, positive effect on the operation performance at the restaurant in Bandung.

H3 : The dimensions of the EO, which consists of innovativeness, proactiveness, competitive aggressiveness, autonomy and risk taking, positive effect on the profitability at the restaurant in Bandung.

\section{RESEARCH METHODS}

The unit of analysis in this study is the restaurant company in Bandung. A total of 112 company restaurants, is taken as a sample, selected by purposive sampling approach. The criteria are determined based on the age of the company, the ownership of indigenous and medium-scale enterprises upward. Given the unit of analysis is a company, the survey respondents was the manager or head of the company.

Data were collected with a questionnaire prepared by the method of rating scale. Questionnaire research to measure the dimensions of EO is measured in a scale interval. Innovativeness (X1) is measured by two indicators, namely the search for new opportunities, and seek new solutions; Proactiveness (X2) measured by three indicators, namely monitor business trends, identify future needs, and the anticipation of change; Competitive aggressiveness (X3) measured by two indicators, namely business outclassing, and priorities for growth; Autonomy (X4) is measured by two indicators, namely the freedom of employees to be creative and autonomous unit for business development; Risk taking (X5) is measured by three indicators, namely the courage to take a business risk, financial risk and personal risk.

Marketing performance (Y1) is measured by two indicators that the growth of sales turnover, and the average growth in the number of customers. Operating performance (Y2) is measured by two indicators is reduction in average production costs, the effectiveness of services. Profitability (Y3) is measured by two indicators of the growth in net profit, and return on investment.

The influence between variables were analyzed with multiple regression, where the significance level was tested with $\alpha=5 \%$. There are three models to be tested: 1 ). The effect of the EO dimension on marketing performance; 20. The effect of EO dimension on operation performance; and 3). The effect of EO dimension on profitability.

\section{RESULT AND DISCUSSION}

\section{A. Impact of EO Dimension On Marketing Performance}

Results of testing the hypothesis 1 , can be seen in Table I. In accordance with the proposed model, the first test is the influence of the dimensions of EO consists of innovativeness, proactiveness, competitive aggressiveness, autonomy and risk taking to performance marketing. Results of statistical analysis showed that all dimensions of EO positive and significant effect on the performance marketing.
The greatest influence is shown by the dimensions of proactiveness, which amounted to $60.2 \%$; followed by autonomy (25.6\%); Risk taking (22.8\%); innovativeness $(10.0 \%)$; and competitive aggressiveness $(8.5 \%)$. All significant at $\alpha=5 \%$.

Why proactiveness dimension gives the strongest impact on the performance of marketing? The explanation is very simple. Proactiveness refer to the company's efforts to capture new opportunities. Organizations that proactively monitor trends, identify the future needs of existing customers, and anticipate changes in demand and the problems that arise that can lead to new business opportunities. Proactiveness not only recognize the change, but also willing to act on their understanding of the competition. Proactiveness implement strategic managers who have an eye on the future in looking for new opportunities to grow and develop. Many companies are proactively looking for ways not only to the future orientation, but also to change the nature of competition in their industry.

\section{TABLE I. EFFECT OF EO DIMENSIONS ON MARKET PERFORMANCE}

\begin{tabular}{|c|c|c|c|c|c|}
\hline \multicolumn{6}{|c|}{ Coefficients } \\
\hline \multirow[b]{2}{*}{ Model } & \multicolumn{2}{|c|}{$\begin{array}{c}\text { Unstandardi } \\
\text { zed } \\
\text { Coefficients }\end{array}$} & \multirow{2}{*}{\begin{tabular}{|c|}
$\begin{array}{c}\text { Standardize } \\
\text { d } \\
\text { Coefficients }\end{array}$ \\
Beta \\
\end{tabular}} & \multirow[b]{2}{*}{$\mathbf{T}$} & \multirow[b]{2}{*}{ Sig. } \\
\hline & $B$ & $\begin{array}{c}\text { Std. } \\
\text { Error }\end{array}$ & & & \\
\hline $1 \quad)^{\text {(Constant }}$ & -1.612 & .156 & & - & .000 \\
\hline $\mathrm{X} 1$ & .100 & .029 & .117 & 3.456 & .001 \\
\hline $\mathrm{X} 2$ & .602 & .070 & .459 & 8.566 & .000 \\
\hline $\mathrm{X} 3$ & .085 & .028 & .099 & 2.969 & .004 \\
\hline $\mathrm{X} 4$ & .256 & .036 & .279 & 7.199 & .000 \\
\hline $\mathrm{X} 5$ & .228 & .032 & .263 & 7.197 & .000 \\
\hline
\end{tabular}

Proactiveness is specifically effective to create a competitive advantage, because it is putting competitors in a position to respond to the initiative successful. The benefit gained by the first company to enter new markets, are building a brand identity, implementing administrative techniques, or adopt new technologies in an industrial operation called first mover advantage.

\section{B. Impact of EO Dimension On Operation Performance}

Next, we test the second hypotesis. The result showed that all the dimensions of EO have a positive and significant impact on operating performance (Table II).

TABLE II. IMPACT OF EO DIMENSIONS ON OPERATION PERFORMANCE

\begin{tabular}{|c|c|c|c|c|c|}
\hline \multicolumn{6}{|c|}{ Coefficients } \\
\hline \multirow[b]{2}{*}{ Model } & \multicolumn{2}{|c|}{$\begin{array}{l}\text { Unstandardized } \\
\text { Coefficients }\end{array}$} & \multirow{2}{*}{\begin{tabular}{|c}
$\begin{array}{c}\text { Standardize } \\
\text { d } \\
\text { Coefficients }\end{array}$ \\
Beta
\end{tabular}} & \multirow[b]{2}{*}{$\mathbf{t}$} & \multirow[b]{2}{*}{ Sig. } \\
\hline & $\boldsymbol{B}$ & Std. Error & & & \\
\hline 1 (Constant) & -.017 & .221 & & -.079 & .937 \\
\hline $\mathrm{X} 1$ & .279 & .080 & .243 & 3.483 & .001 \\
\hline $\mathrm{X} 2$ & .168 & .056 & .198 & 2.973 & .004 \\
\hline $\mathrm{X} 3$ & .193 & .073 & .204 & 2.658 & .009 \\
\hline $\mathrm{X} 4$ & .285 & .062 & .310 & 4.619 & .000 \\
\hline X5 & .113 & .047 & .141 & 2.397 & .018 \\
\hline
\end{tabular}


Autonomy provides the greatest contribution to the improvement of the operating performance of $28.5 \%$; Innovativeness contributed 27.9\%; Aggressiveness contributed 19.3\%; Proactiveness affects 16.8\%; and Risk Taking $11.3 \%$ impact on the improvement of operating performance. At the level of $\alpha=5 \%$, entirety significant.

Why dimensions of autonomy provides the greatest contribution to the performance of the operation? Autonomy refers to the desire to act independently in order to continue the entrepreneurial vision or opportunity. It is applied to both individual and team that operates outside of strategies and norms that have been there from an organization. In the context of corporate entrepreneurship, autonomous work units are often used to leverage existing strengths in the new arena, identify opportunities of organizational capability at present, and encourages the development of new businesses or improve business practices.

Based on the explanation, it is entirely possible that the dimensions of the largest autonomy contribute to the operating performance, due to operating problems, the employees know more real conditions that occur. When they are given autonomy and discretion to make a decision, then the problems become more easily completed operations, which in turn will collectively improve operating performance.

\section{Impact of EO Dimension On Profitability}

In the third hypothesis testing, it appears that the dimensions of EO also has a significant and positive impact on profitability (See Table III). The test results show that the dimensions of autonomy contribute to the spread of $22.5 \%$; innovativeness contributed $22.3 \%$; aggressiveness $21.6 \%$; risk taking $16.1 \%$; and proactiveness $15.7 \%$.

TABLE III. IMPACT OF EO DIMENSION ON PROFITAILITY

\begin{tabular}{|c|c|c|c|c|c|}
\hline \multirow[b]{3}{*}{ Model } & \multicolumn{3}{|c|}{ Coefficients } & \multirow[b]{3}{*}{$\mathbf{T}$} & \multirow[b]{3}{*}{ Sig. } \\
\hline & \multicolumn{2}{|c|}{$\begin{array}{c}\text { Unstandardized } \\
\text { Coefficients }\end{array}$} & \multirow{2}{*}{\begin{tabular}{|c|}
$\begin{array}{c}\text { Standardize } \\
\mathbf{d} \\
\text { Coefficients }\end{array}$ \\
Beta \\
\end{tabular}} & & \\
\hline & $B$ & $\begin{array}{c}\text { Std. } \\
\text { Error }\end{array}$ & & & \\
\hline 1 (Constant) & .141 & .253 & & .559 & .577 \\
\hline $\mathrm{X} 1$ & .223 & .086 & .208 & 2.598 & .011 \\
\hline $\mathrm{X} 2$ & .157 & .064 & .186 & 2.462 & .015 \\
\hline $\mathrm{X} 3$ & .216 & .089 & .213 & 2.415 & .017 \\
\hline $\mathrm{X} 4$ & .225 & .071 & .245 & 3.197 & .002 \\
\hline $\mathrm{X} 5$ & .161 & .052 & .200 & 3.108 & .002 \\
\hline
\end{tabular}

Profitability is often used as a major component of business performance. The main consideration of a decision in business is generally associated with profitability. This means that a decision would be judged worthy (feasible) if a positive impact on the profitability of the company. Basically, the dimensions of EO is an approach in taking strategic decisions. Therefore, it is reasonable if every dimension EO positive and significant impact on profitability.

\section{CONCLUSION AND IMPLICATION}

Partially, the dimensions of EO positive and significant impact on business performance consisting of marketing performance, operating performance and profitability, especially in the restaurant business. This result also confirms the results of previous research on the effects of EO on the performance of the business, where almost all studies show positive effects. In addition, the study uncovered more specifically, that turns each dimension EO if separated, have a diverse impact on performance. Proactiveness the greatest influence on the performance marketing, while the autonomy provided the largest contribution to the operating performance and profitability. However, innovativeness, competitive aggressiveness, autonomy and risk taking also had a significant impact on the performance marketing, operating performance and profitability.

The results of this study provide some important implications. First, it is proper business units strengthen the entrepreneurial orientation in all dimensions. All dimensions of the EO, as important and provide a positive impact for the company's performance. Second, for the restaurant business, the study recommends that the primary capital to be able to sustain themselves in the competition is to strengthen the EO. The dimensions of EO should be part of the culture in the company. Third, for further research, this study can be developed and expanded its scope, both the addition of variable or unit of analysis.

\section{REFERENCES}

[1] Handaru, Agung Wahyu., Pagita, Magdalena Prita., Parimita Widya. 2015. Karakteristik entrepreneur melalui Multiple Diskriminan Analisis (Studi pada etnis Tionghoa, Jawa dan Minang di Bekasi Utara. Jurnal Riset Manajemen Sains Indonesia (JRMSI). Vol No. 1. 2015. PP 351-375.

[2] Eroglu, Osman \& Picak, Murat. 2011. Entrepreneurship, National Culture and Turkey. International Journal Of Business and Social Science. Vol 2 No 16. September 20111. PP 146 - 151.

[3] Anlesinya, Alex., Patrick Eshun., Amy Efi Bonuedi. 2015. Entrepreneurial Orientation Dimensions And Profitability Nexus: Evidence From Micro Enterprises In The Retail Sector In A Developing Country. International Journal Of Small Business and Entrepreneurship Research. Vol 3 No 7 PP 79-87.

[4] Venter, R. \& Calaghan, C. 2011. An investigation of the entrepreneurial orientation, context and entrepreneurial performance of inner-city Johannesburg street traders. Southern African Business Review. Vol 15 No 1. Pp $28-48$.

[5] Lumpkin, GT., Dess, Gregory G. 2001. Linking Two Dimension Of Entrepreneurial Orientation To Firm Performance : The Moderating Role Of Environment and Industry Life Cycle. Journal of Business Venturing. 16. Pp $429-451$.

[6] Freiling, Jorg. \& Schelhowe, Christoph Lutke. 2014. Impact of Entrepreneurial Orientation On The Performance of Internationalization. Journal of Entrepreneurship Management and Innovation (JEMI). Vol 10 Issue 4. PP 169-199.

[7] Baker, William E., Sinkula, James M. 2009. The Complementary effect of Market Orientation and Entrepreneurial Orientation On Profitability in Small Business. Journal Of Small Business Management. Vol 47 (4) pp 443-464.

[8] Campos, Hector Montiel, Jose Pablo Nuno De La Parra., Francesc Solle Parrellada. 2012. The Entrepreneurial Orientation-Dominan LogicPerformance Relationship In New Ventures: An Exploratory Quantitative Study. Brazilian Administration Review (BAR). Vol 9 Art 4. Pp 60-77.

[9] Mwangi, M MA. \& Ngugi,. 2014. Influence of Entrepreneurial Orientation On Growth of Micro and Small Enterprise In Kerugoya, Kenya. European Journal Of Business Management. Vol 1. Issue 11. 417 438.

[10] Lumpkin, GT. \& Gregory G Dess. 1996. Clarifying the Entrepreneurial Orientation Construct and linking IT to Performance. Academy of Management Review, Vol. 21 No. 1. Pp 135-172

[11] Jun, Zhan., 2002. Exploring Entrepreneurial Orientation (EO) in 3 Dimensions: a New Prospective for Analyzing the Value of a company.

[12] Stam, Wouter \& Tom Elfring. 2008. Entrepreneurial Orientation and New Venture Performance: The Moderating Role of Intra- and Extraindustry Social Capital. Academy of management Journal. Vol. 51 No.1. Pages 97111. 
[13] Rauch, Andreas., Johan Wiklund, GT Lumpkin \& Michael Frese. 2004. Entrepreneurial Orientation and Business Performance: An Assesment of Past Research and Suggestions for The Future. Babson-Kauffman Entrepreneurship Research Conference in Glasgow, Scotland.

[14] Regan, Padraic. 2007. The Relationships Between Entrepreneurial Orientation, Organization Structure, and Ownership in The European Airport Industry.

[15] Yang, Chung-Wen. 2007. The Relationships among Leadership Styles, entrepreneurial Orientation, and Business Performance. Managing Global Transitions 6(3) : 257-275.

[16] Mahmood,R. \& Hanafi, N. (2013). Entrepreneurial Orientation and Business Performance of Women-Owned Small and Medium Enterprises in Malaysia: Competitive Advantage as a Mediator. International Journal of Business and Social Science 4(1) 82-90.

[17] Wiklund, J., \& Shepherd, D. (2005). Entrepreneurial orientation and small business performance: A configurational approach. Journal of Business Venturing, 20, 71-91.

[18] Frank, H., Kessler, A., \& Fink, M. (2010). Entrepreneurial orientation and business performance - a replication study. Schmalenbach Business Review, 62, 175-198.

[19] Dess, George G., GT. Lumpkin., Alan B. Eisner. 2006. Strategic Management 3e. Text and Cases. McGraw-Hill.

[20] Frank, H., Kessler, A., \& Fink, M. (2010). Entrepreneurial orientation and business performance - a replication study. Schmalenbach Business Review, 62, 175-198.
[21] Yang, Chung-Wen. 2007. The Relationships among Leadership Styles, entrepreneurial Orientation, and Business Performance. Managing Global Transitions 6(3) : 257-275.

[22] Stam, Wouter \& Tom Elfring. 2008. Entrepreneurial Orientation and New Venture Performance: The Moderating Role of Intra- and Extraindustry Social Capital. Academy of management Journal. Vol. 51 No.1. Pages 97 111.

[23] Andersen, Jim. 2010. A Critical Examination of The EO-Performance Relationship. International Journal of entrepreneurial Behaviour \& Research. Vol. 16 No. 4 pp. 309-328. Emerald Group Publishing limited.

[24] Rauch, Andreas., Johan Wiklund, GT Lumpkin \& Michael Frese. 2004 Entrepreneurial Orientation and Business Performance: An Assesment of Past Research and Suggestions for The Future. Babson-Kauffman Entrepreneurship Research Conference in Glasgow, Scotland.

[25] Stam, Wouter \& Tom Elfring. 2008. Entrepreneurial Orientation and New Venture Performance: The Moderating Role of Intra- and Extraindustry Social Capital. Academy of management Journal. Vol. 51 No.1. Pages 97111.

[26] Frank, H., Kessler, A., \& Fink, M. (2010). Entrepreneurial orientation and business performance - a replication study. Schmalenbach Business Review, 62, 175-198.

[27] Dess, George G., GT. Lumpkin., Alan B. Eisner. 2006. Strategic Management 3e. Text and Cases. McGraw-Hill. 